\title{
Keabsahan Surat Keputusan Gubernur Jawa Tengah Pasca Putusan Mahkamah Agung Tentang Penambangan Pabrik Semen
}

\author{
Zainuddin Amriti Albar
}

Zainuddin Amriti Albar; Fakultas Hukum Universitas Brawijaya; Jl. MT Haryono 169; Malang; 65145; Jawa Timur; Indonesia.

\begin{tabular}{l} 
A R T I C L E I N F O \\
\hline Article history: \\
Received 2019-05-09 \\
Received in revised form \\
2019-06-19 \\
Accepted 2019-07-01
\end{tabular}

Kata kunci:

Surat Keputusan Gubernur,

Peninjauan Kembali,

Penambangan Pabrik Semen.

Keywords:

Governor's Decree, Review,

Cement Plant Mining.

\section{Citation:}

Albar, Z. (2019). Keabsahan Surat Keputusan Gubernur Jawa Tengah Pasca Putusan Mahkamah Agung Tentang Penambangan PabrikSemen. Jurnal Cakrawala Hukum, 10(1). doi:10.26905/idjch.v10i1.3117

\begin{abstract}
Abstrak
Penelitian ini bertujuan untuk mengkaji keabsahan Surat Keputusan Gubernur Jawa Tengah Nomor 660.1/6 Tahun 2017 tentang izin pembangunan dan penambangan pabrik semen setelah adanya pembatalan Surat Keputusan Gubernur yang terdahulu oleh Mahkamah Agung Nomor 99 PK/TUN/2016. Mahkamah Agung membatalkan pembangunan dan penambangan pabrik semen karena banyak memberikan dampak negatif bagi lingkungan. Penambangan pabrik semen dikawasan Rembang dinyatakan tidak sesuai dengan analisis dampak lingkungan karena dalam wilayah penambangan pabrik semen tersebut terdapat Cekungan Air Tanah yang kelestariannya dilindungi oleh Undang-Undang. Penelitian ini termasuk jenis penelitian normatif. Penelitian yang telah dilakukan diperoleh hasil bahwa secara subtansial Surat Keputusan gubernur Jawa Tengah Nomor 660.1/6 Tahun 2017 dinyatakan tidak sah meskipun dengan alasan adanya perbaikan AMDAL karena keputusan Mahkamah Agung selaku peradilan tertinggi yang setiap keputusannya tidak dapat diganggu gugat. Namun yang menjadi saran seharusnya isi putusan Mahkamah Agung tidak menimbulkan persepsi bahwa pembangunan dilanjutkan dengan mengubah AMDAL.
\end{abstract}

\begin{abstract}
This study aims to examine the validity of the Central Java Governor Decree Number 660.1 / 6 of 2017 concerning permits for the construction and mining of cement factories after the cancellation of the previous Governor's Decree by the Supreme Court Number 99 PK / TUN / 2016. The Supreme Court overturned the construction and mining of cement factories because they had a negative impact on the environment. Mining of cement plants in the Rembang area is declared not in accordance with the environmental impact analysis because in the mining area of the cement plant there is a Groundwater Basin whose preservation is protected by law. This research includes the type of normative research. The research that has been
\end{abstract}


Jurnal Cakrawala Hukum, Volume 10 No. 1 Juni 2019

ISSN PRINT 2356-4962 ISSN ONLINE 2598-6538

carried out has been obtained that substantially the Central Java Governor Decree Number 660.1 / 6 of 2017 was declared invalid even though on the grounds that there was an improvement in the EIA because of the Supreme Court's decision as the highest court that every decision could not be contested. However, the suggestion should be that the contents of the Supreme Court's ruling did not lead to the perception that the development was continued by changing the EIA.

\section{Latar Belakang}

Lingkungan merupakan suatu hal yang tidak dapat dipisahkan dari kehidupan manusia. Akhirakhir ini sering kali ditemukannya suatu pengerusakan lingkungan oleh manusia dengan alasan pemanfaatan untuk menghasilkan materi yang lebih, secara tidak langsung tindakan ini mengakibatkan terkikisnya lingkungan dan mengancam pada kelangsungan hidup manusia. Salah satu contoh kerusakan di lingkungan dikarenakan adanya proses pembangunan baik pembangunan pemukiman maupun pabrik.

Mempertimbangkan dampak negatif tidak sedikit dalam proses pembangunan mengalami pro kontra. Banyak masyarakat yang menganggap bahwa pembangunan memilik dampak negatif apalagi pembangunan pabrik. Pabrik yang dibangun diarea pertanian atau pegunungan sangat sulit mendapatkan izin pendirian bangunan oleh pemerintah setempat (Abe, 1994). Selain dapat merusak lingkungan, ditakutkan dapat mematikan sektor perekonomian rakyat sekitar. Pemberian izin oleh Gubernur Jawa Tengah, yaitu Surat Keputusan (SK) Gubernur No 660.1/30 tahun 2016 yang menyatakan bahwa izin untuk penambangan dan pembangunan pabrik semen PT Semen Indonesia. Hal ini menimbulkan banyak sekali protes dari kalangan masyarakat dan LSM namun akhirnya Mahkamah Agung mengeluarkan Peninjauan Kembali (PK) Putusan Mahkamah Agung No 99 PK/TUN/2016 yang menyatakan membatalkan izin atas surat izin yang dikeluarkan oleh Gubernur Jawa Tengah.
Mahkamah Agung menyatakan bahwa Gubernur Jawa Tengah menggunakan cara administratif lain yang dipandang bertentangan dengan penyelenggaraan kekuasaan asas-asas umum pemerintahan yang baik (Sibuea, 2010). Mahkamah Agung mempertimbangkan secara substansial bahwa yang pokoknya menyampaikan bahwa terbukti penyusunan dokumen AMDAL mengandung cacat prosedural, sehingga keputusan obyek sengketa yang diterbitkan berdasarkan dokumen AMDAL secara mutis muntadis mengandung cacat yuridis pula (Kaloh, 2009). Oleh karena itu patut dinyatakan batal.

Namun tidak lama berselang pada 23 Februari 2017 Gubernur Jawa Tengah mengeluarkan Surat Keputusan Gubernur Nomor 660.1/6 Tahun 2017 ini tentang izin lingkungan kegiatan penambangan dan pembangunan pabrik semen PT Semen Indonesia di Kabupaten Rembang. Hal ini berdasar kepada hasil rapat Komisi Penilai AMDAL dalam rangka penilaian adendum AMDAL dan rencana pengelolaan lingkungan-rencana pemantauan lingkungan pada 2 Februari 2017, yang hasilnya pabrik semen di Rembang dapat direkomendasikan layak lingkungan hidup.

Komisi Penilai AMDAL diikuti berbagai unsur, yaitu pemerintah, pakar dari berbagai perguruan tinggi, LSM atau pemerhati lingkungan, dan masyarakat yang terkena dampak. Gubernur Jawa Tengah menyatakan bahwa perbaikan AMDAL yang dilakukan oleh PT Semen Indonesia telah mengalami perbaikan dan tidak menimbukan dampak negatif terutama mengganggu lingkungan. 
Dalam sidang addendum AMDAL 2 Februari, Komisi Penilai AMDAL menilai penyempurnaan AMDAL Semen Indonesia memenuhi 10 kriteria Peraturan Menteri LHK Nomor 8/2013.

Dokumen AMDAL menyatakan, layak direkomendasikan pada Gubernur Ganjar Pranowo, dengan tambahan catatan memperbanyak sumur resapan sebagai langkah konkret penerapan zero sun off air hujan di dalam tanah. Pengelolaan dan pemantauan lingkungan, wajib melibatkan masyarakat. Pembuatan embung dan pemanfaatan harus jangka panjang. Air embung harus bisa jadi solusi kebutuhan air bersih warga dan irigasi pertanian. Termasuk reklamasi Semen Indonesia harus pakai bahan organik. PT. Semen Indonesia Perusahaan Semen Indonesia menyebutkan, beberapa dokumen perbaikan sudah diserahkan ke Dinas Lingkungan Jawa Tenggh antara lain tata cara penambangan dan upaya membantu masyarakat setempat dalam pengadaan air guna memenuhi kebutuhan hidup sehari-hari.

Selain banyaknya pertanyaan terhadap keputusan Gubernur Jawa Tengah, penulis juga mempertanyakan dasar yang kurang jelas dan kurang tegas dari Peninjauan Kembali Mahkamah Agung terhadap putusan Gubernur Jawa Tengah sehingga mengakibatkan Gubernur Jawa Tengah dapat mengeluarkan kembali Surat Keputusan yang baru. Dasar yang digunakan Mahkamah Agung sebagai dasar pengambilan keputusan yaitu, UndangUndang Republik Indonesia Nomor 7 Tahun 2004 tentang Sumber Air, Undang-Undang Republik Indonesia Nomor 26 Tahun 2007 tentang Penataan Ruang, Undang-Undang Republik Indonesia Nomor 28 Tahun 2008 tentang Rencana Tata Ruang Wilayah Nasional, Undang-Undang Republik Indonesia Nomor 32 Tahun 2009 tentang Perlindungan dan Pengelolaan Lingkungan Hidup, Perda Jateng tentang Rencana Tata Ruang Wilayah Provinsi Jateng Tahun 2010-2030, Keputusan Presiden No 26 Tahun 2011 tentang Penetapan Cekungan Air Tanah, dan Perda Kabupaten Rembang No 14
Tahun 2011 tentang RT/RW Kabupaten Tahun 2011-2031 Jo Keputusan Presiden No 26 Tahun 2011 tentang Penetapan Cekungan Air Tanah. Melihat dasar putusan tersebut, seharusnya isi putusan Mahkamah Agung tidak menimbulkan persepsi bahwa pembangunan dapat dilanjutkan dengan mengubah AMDAL.

\section{Metode}

Penelitian hukum merupakan suatu proses untuk menemukan aturan hukum, prinsip-prinsip hukum, maupun doktrin hukum guna menjawab isu hukum yang dihadapi. Penelitian hukum dilakukan untuk menghasilkan argumentasi, teori ataupun konsep baru sebagai deskripsi dalam menyelesaikan masalah yang dihadapi (Marzuki, 2017). Jenis Penelitian dalam penelitian ini adalah penelitian normatif, yaitu penelitian hukum yang dilakukan dengan cara meneliti bahan- bahan hukum primer dan bahan-bahan hukum sekunder yang disusun secara sistematis, dikaji, kemudian ditarik suatu simpulan dalam hubungannya dengan masalah yang diteliti. Hukum normatif (normative legal reaserch), yaitu penelitian yang dilakukan dengan cara mengaji peraturan perundangundangan yang berlaku atau diterapkan dalam suatu permasalahan hukum tertentu (Soerjono, 2003).

Penelitian ini seringkali disebut penelitian doktrinal, penelitian yang obyek kajiannya adalah dokumen peraturan perundang-undangan dan bahan pustaka (Mertokusumo, 2005). Pendekatan Normatif adalah pendekatan yang menelaah hukum sebagai kaidah yang dianggap sesuai dengan penelitian yuridis normatif atau penelitian hukum tertulis atau penelitian hukum yang doktrinal, yang bekerja untuk menemukan jawaban-jawaban yang benar dengan pembuktian kebenaran yang dicari dari preskripsi-preskripsi hukum yang tertulis di kitab undang-undang (Ali, 2013). Dengan singkatnya bahwa penelitian yuridis normatif membahas doktrin-doktrin atau asas-asas dalam ilmu hukum (Nasution, 2013). 


\section{Jurnal Cakrawala Hukum, Volume 10 No. 1 Juni 2019}

ISSN PRINT 2356-4962 ISSN ONLINE 2598-6538

Penelitian ini mengaji tentang keabsahan surat keputusan Gubernur Nomor 660.1/6 Tahun 2017 ini tentang izin lingkungan kegiatan penambangan dan pembangunan pabrik semen PT Semen Indonesia di Kabupaten Rembang Jawa Tengah. Dalam hal ini Gubernur Jateng sempat membatalkan SK terhadulu akibat adanya PK dari MA hal ini dikarenakan adanya permasalahan pada dampak terhadap lingkungan yang mungkin diakibatkan adanya pembangunan pabrik semen.

Pendekatan Penelitian yang digunakan adalah pendekatan undang-undang (statue approach) dan pendekatan konsep (conceptual approach) (Marzuki, 2005). Pendekatan perundangundangan dilakukan untuk meneliti penerbitan SK oleh Gubernur Jateng tentang pembangunan pabrik semen di Rembang Jawa Tengah. Pendekatan konsep dilakukan untuk memahami konsep kepemimpinan Gubernur Jawa tengah terhadap masyarakat yang tinggal di sekitar pabrik semen maupun dampak negatif bagi lingkungan sekitar. Konsep kepemimpinan yang mencangkup konsep perlindungan hukum terhadap masyarakat dan lingkungan sekitar.

\section{Pembahasan}

\section{A. Kronologi Kasus}

14 Oktober 2010, Pemerintah daerah memberikan ijin pembangunan pabrik semen dengan mengeluarkan Keputusan Bupati Nomor 545/68/ 2010 mengenai Wilayah Izin Usaha Pertambangan (WIUP). Surat keputusan ini diikuti dengan adanya Pemberian Izin Lokasi Eksplorasi untuk pembangunan pabrik semen, lahan tambang bahan baku, dan sarana pendukung lainnya dengan nomor 591/40/2011.

Tahun 2014, terjadi bentrok antara PT Semen Indonesia (Persero) dengan warga Kendeng saat agenda peletakan batu pertama tambang semen. Warga Kendeng mengatakan bahwa mereka tidak diberikan informasi mengenai pembangunan pabrik semen di wilayah desa mereka. Sosialisasi hanya dilakukan oleh kepala daerah terkait tanpa memberitahu warga Kendeng. Dokumen AMDAL juga tidak disampaikan kepada warga Kendeng. Oleh karena itu, dampak-dampak negatif akibat pembangunan pabrik semen tidak diketahui oleh masyarakat. Pembangunan pabrik semen ini juga menyalahgunakan peraturan yang sudah ada diantaranya,

Penggunaan kawasan cekungan air tanah Watuputih sebagai area penambangan batuan kapur untuk bahan baku pabrik semen melanggar Perda Rencana Tata Ruang Wilayah (RTRW) Provinsi Jawa Tengah Nomor 6 Tahun 2010 pasal 63 yang menetapkan area ini sebagai kawasan lindung imbuhan air dan Perda RTRW Kabupaten Rembang Nomor 14 Tahun 2011 pasal 19 yang menetapkan area ini sebagai kawasan lindung geologi. Kemudian, penebangan kawasan hutan tidak sesuai dengan Persetujuan prinsip tukar menukar kawasan hutan oleh Menteri Kehutanan, surat Nomor S. 279/Menhut-II/2013 tertanggal 22 April 2013, dalam surat tersebut menyatakan bahwa kawasan yang diizinkan untuk ditebang adalah kawasan hutan KHP Mantingan yang secara administrasi Pemerintahan terletak pada Desa Kajar dan Desa Pasucen kecamatan Gunem Kabupaten Rembang provinsi Jawa Tengah. Namun fakta di lapangan, Semen Indonesia menebang kawasan hutan Kadiwono kecamatan Bulu seluas kurang lebih 21, 13 hektar untuk tapak pabrik. Perlu diketahui dalam Perda nomor 14 tahun 2011 tentang RT/RW Kabupaten Rembang Kecamatan Bulu tidak diperuntukkan sebagai kawasan industri besar.

Warga Kendeng yang menolak pembangunan pabrik semen ini menggugat PT Semen Indonesia (Persero) atas penerbitan izin lingkungan kegiatan penambangan karst dan pembangunan pabrik semen ke Mahkamah Agung (MA). Kasus ini berawal dari gugatan petani Kendeng bersama Yayasan Wahana Lingkungan Hidup (Walhi) ke 
Pengadilan Tata Usaha Negara (PTUN) Semarang. Namun gugatan tersebut ditolak dengan alasan kedaluwarsa. Lalu mereka kembali mengajukan banding ke PT TUN Surabaya. Tetapi banding juga ditolak. Setelah kedua pernolakan tersebut, petani Kendeng dan Walhi mengajukan kasasi ke MA dan kembali ditolak. Akhirnya pada tanggal 2 Agustus 2016, petani Kendeng dan Walhi menemukan bukti baru yang dibawa untuk memberatkan Gubernur Jawa Tengah dan PT Semen Indonesia (Persero) dan MA mengabulkan permohonan yang mereka ajukan. Oktober 2016, lewat keputusan Mahkamah Agung, memutuskan memenangkan petani Kendang dan Yayasan Wahana Lingkungan Hidup (Walhi) dan membatalkan izin lingkungan tersebut. Artinya, surat keputusan Gubernur Jawa Tengah, Ganjar Pranowo, terhadap PT Semen Indonesia harus dibatalkan.

Oktober 2016, lewat keputusan Mahkamah Agung, memutuskan memenangkan petani Kendang dikeluarkan pada 23 Februari 2017. Izin itu dikeluarkan setelah dilaksanakan rapat komisi penilai AMDAL pada 2 Februari 2017 menyepakati bahwa pembangunan pabrik semen Indonesia di Rembang direkomendasikan layak lingkungan hidup. Keputusan Ganjar menerbitkan izin baru ini langsung mendapat respons negatif dari warga dan para aktivis lingkungan. Izin tersebut dianggap melanggar aturan hukum lantaran melanggar putusan Mahkamah Agung Nomor 99 PK/TUN/ 2016 Tahun 2016. Penanyangan konten mengenai konflik pembangunan pabrik semen di Pegunungan Kendang kerap mewarnai layar kaca Indonesia, terutama pada acara berita. Konten yang disajikan berupa aksi demonstrasi warga Kendeng baik di wilayah Jawa Tengah maupun di Jakarta.

\section{B. Keabsahan Surat Keputusan Gubernur Nomor 660.1/6 Tahun 2017 terkait Putusan Mahkamah Agung Nomor 99 PK/TUN/2016 tentang Pembatalan Izin Penambangan Semen \\ Penerbitan Surat Keputusan Gubernur Nomor 660.1/6 Tahun 2017 tentang izin Lingkungan}

Kegiatan Penambangan dan Pembangunan Pabrik Semen PT Semen Indonesia di Kabupaten Rembang setelah Surat putusan Mahkamah Agung tentang pembatalan SK Gubernur Jateng sebelumnya menimbulkan respon negatif di kalangan masyarakat. Selain hal-hal yang merugikan masyarakat, keabsahan SK Gubernur Jateng terbaru juga diduga menyalahi atau pembangkangan terhadap hukum. Berikut analisa mengenai berbagai dugaan pelanggaran Gubernur Jateng melalui Surat Keputusan Gubernur Nomor 660.1/6 Tahun 2017:

1. Keputusan Presiden Republik Indonesia Nomor 26 Tahun 2011 tentang Penetapan Cekungan Air Tanah

2. Undang-Undang Republik Indonesia Nomor 26 Tahun 2007 tentang Penataan Ruang Juncto Peraturan Pemerintah Republik Indonesia Nomor 26 Tahun 2008 tentang Rencana Tata Ruang Wilayah Nasional

3. Undang-Undang Republik Indonesia Nomor 32 Tahun 2009 tentang Perlindungan dan Pengelolaan Lingkungan Hidup

4. Peraturan Daerah Jawa Tengah Nomor 6 Tahun 2010 tentang Rencana Tata Ruang Wilayah Provinsi Jawa Tengah Tahun 2010 2030 Juncto Keputusan Presiden Republik Indonesia Nomor 26 Tahun 2011 tentang

5. Peraturan Daerah Kabupaten Rembang Nomor 14 Tahun 2011 tentang RT/RW Kabupaten Tahun 2011 - 2031 Juncto Keputusan Presiden Republik Indonesia Nomor 26 Tahun 2011 tentang Penetapan Cekungan air tanah.

6. Peraturan Pemerintah Nomor 43 Tahun 2008 tentang Air

7. Laporan Amdal yang tidak sesuai dengan keadaan dilapangan

AMDAL yang menjadi dasar keluarnya SK Kelayakan Lingkungan yang kemudian menjadi dasar keluarnya Izin Lingkungan ternyata tidak berdasarkan informasi yang benar (Hadjon, 1994). Sehingga berdasar keputusan hakim Mahkamah Agung memutuskan bahwa, mengabulkan gugatan 
Penggugat untuk seluruhnya dan menyatakan batal serta mencabut Surat Keputusan Gubernur Jawa Tengah Nomor 660.1/17 Tahun 2012, tanggal 7 Juni 2012, tentang Izin Lingkungan Kegiatan Penambangan oleh PT Semen Gresik (Persero) Tbk, di Kabupaten Rembang, Provinsi Jawa Tengah.

Lahirnya Putusan Mahkamah Agung yang memutus upaya hukum Peninjauan Kembali atas gugatan warga Rembang lewat Putusan MA Nomor 99 PK/TUN/2016 seharusnya menjadi titik terang perjuangan warga Rembang selama bertahuntahun dalam upaya pelestarian lingkungan. Dalam masa keharusannya melaksanakan isi putusan tersebut, Gubernur justru menerbitkan Keputusan Gubernur Nomor 660.1/6 Tahun 2017 tentang Izin Lingkungan Kegiatan Penambangan dan Pembangunan Pabrik PT Semen Indonesia yang tidak sejalan dengan perintah putusan MA tersebut. Hal itu jelas telah menciderai konsep Negara Hukum yang dianut oleh Negara Indonesia. Karena idealnya Negara Hukum adalah, yang harus dijadikan panglima dalam dinamika kehidupan kenegaraan adalah hukum, bukan politik ataupun ekonomi (Supriatna, 1996). Izin Lingkungan tersebut tidak sah secara hukum karena bertentangan dengan banyak peraturan perundang-undangan yang ada sehingga izin tersebut mengandung cacat hukum, kekeliruan, penyalahgunaan, serta ketidakbenaran dan/ atau pemalsuan data, dokumen, dan/ atau informasi, namun sampai saat ini oprasional pabrik PT Semen Indonesia telah berjalan dengan dasar legaliltas Izin Lingkungan baru tersebut.

\section{Status Surat Putusan Mahkamah Agung Nomor 99 PK/TUN/2016 tentang Penambangan Pabrik Semen dalam Struktur Perundang-Undangan}

UU No14 Tahun 1985, bahwa peradilan harus memenuhi harapan para pencari keadilan yang selalu menghendaki peradilan yang sederhana, cepat, tepat, adil, dan biaya ringan. Seiring dengan prinsip tersebut di atas serta sebagai upaya untuk mewujudkan sistem peradilan yang lebih efektif dan efisien dalam penyelenggaraan kekuasaan kehakiman di negara hukum Republik Indonesia, maka dalam Undang-undang ini ditegaskan bahwa Mahkamah Agung adalah Pengadilan Negara Tertinggi dari semua Lingkungan Peradilan (Sunarno, 2009). UU No 5 Tahun 2005 Pasal 1 juga menjelaskan bahwa Mahkamah Agung adalah salah satu pelaku kekuasaan kehakiman sebagaimana dimaksud dalam Undang-Undang Dasar Negara Republik Indonesia Tahun 1945.

UU No 24 Tahun 2003, Mahkamah Agung memiliki empat wewenang MA yang tercantum dalam pasal 30, 31 dan 32, MA memiliki peranan yang penting dalam menentukan arah hukum sekaligus memutuskan ada tidaknya pelanggaran konstitusi yang terjadi baik yang dilakukan oleh individu atau lembaga negara ataupun yang terdapat di dalam suatu produk Undang-Undang. Undang-Undang No 12 Tahun 2012 tentang Tata Urutan Perundang-Undangan pasal 7 ayat 1 menjelaskan tentang jenis dan hierarki peraturanperundang-undangan, terdiri atas (Febrian, 2004):

1. Undang-Undang Dasar Negara Republik Indonesia Tahun 1945

2. Ketetapan Majelis Permusyawaratan Rakyat;

3. Undang-Undang/Peraturan Pemerintah Pengganti Undang-Undang;

4. Peraturan Pemerintah;

5. Peraturan Presiden;

6. Peraturan Daerah Provinsi; dan

7. Peraturan Daerah Kabupaten/Kota.

Ayat 2 menjelaskan bahwa Kekuatan Hukum Peraturan Perundang-undangan sesuai dengan hierarki sebagaimana dimaksud pada ayat (1). Putusan Mahkamah Agung dalam hierarki peraturan perundang-undangan termasuk dalam Ketetapan Majelis Permusyawaratan Rakyat, sesuai pasal 8 ayat 1 UU No 12 Tahun 2011 Pasal 7 ayat (1) dan diteruskan pada pasal 9 ayat (2) dapat diketahui bahwa Mahkamah Agung merupakan tinggi negara sebagaimana yang tercantum dalam Ketetapam 
Majelis Permusyarawatan Rakyat Republik Indonesia Nomor III/MPR/1978 dan UU N0 14 Tahun 1985 Mahkamah Agung merupakan Lembaga Peradilan tertinggi dari semua lembaga peradilan yang dalam melaksanakan tugasnya terlepas dari pengaruh pemerintah dan pengaruh-pengaruh lainnya. Mahkamah Agung membawai 4 badan peradilan yaitu Peradilan Umum, Peradilan Militer, Peradilan Agama, dan Peradilan Tata Usaha Negara. Sejak Amandemen Ke-3 UUD 1945 kedudukan Mahkamah Agung tidak lagi menjadi satusatunya puncak kekuasaan kehakiman, dengan berdirinya Mahkamah Konstitusi pada tahun 2003 puncak kekuasaan kehakiman menjadi 2, Mahkamah Agung dan Mahkamah Konstitusi, namun tidak seperti Mahkamah Agung, Mahkamah Konstitusi tidak membawahi suatu badan peradilan (Sutedi, 2013).

Polemik mengenai putusan Mahkamah Agung terjadi pada kasus pembangunan semen di kabupaten Rembang Jawa Tengah. Peninjauan Kembali Mahkamah Agung Nomor 99 PK/TUN/ 2016, putusan MA memberikan pertimbangan berkaitan dengan hal substansial yang pokoknya menyampaikan bahwa terbukti penyusunan dokumen AMDAL mengandung cacat prosedur, sehingga keputusan objek sengketa yang diterbitkan berdasarkan dokumen AMDAL tersebut secara mutatis mutandis mengandung cacat yuridis pula. Oleh karena itu, Putusan MA Nomor 99/PK/TUN 2016 tertanggal 5 Oktober 2016 menyatakan bahwa pembangunan pabrik semen Indonesia di Rembang mengindikasikan banyak terjadi penyelewengan dalam proses pembangunan pabrik tersebut, yang mana dalam putusannya menyatakan: Mengabulkan gugatan para penggugat untuk seluruhnya.

Menyatakan batalSurat Keputusan Gubernur Jawa Tengah Nomor: c, tentang Izin Lingkungan kegiatan penambangan oleh PT. Semen Gresik (Persero) Tbk. di Kabupaten Rembang Jawa Tengah. Mewajibkan kepada tergugat untuk mencabut Surat Keputusan Gubernur Jawa Tengah Nomor
660.1/17 Tahun 2012 tanggal 7 Juni 2012 sebagaimana telah diubah dengan Keputusan Gubernur Jawa Tengah Nomor 660.1/30 Tahun 2016 tanggal 9 November 2016 tentang Izin Lingkungan Kegiatan Penambangan Bahan Baku Semen dan Pembangunan Serta Pengoperasian Pabrik Semen PT. Semen Indonesia (Persero) Tbk di Kabupaten Rembang, Provinsi Jawa Tengah dinyatakan batal.

Menyikapi Putusan Peninjauan Kembali Mahkamah Agung Republik Indonesia Nomor 99 PK/TUN/2016 tanggal 5 Oktober 2016, Tanggal 16 Januari 2017 Gubernur Jawa Tengah, Ganjar Pranowo mengeluarkan Keputusan Gubernur Jawa Tengah Nomor 660.1/4 Tahun 2017 Tentang Pencabutan Keputusan Gubernur Jawa Tengah Nomor 660.1/30 Tahun 2016 Tentang Izin Lingkungan Kegiatan Penambangan Bahan Baku Semen Dan Pembangunan Serta Pengoperasian Pabrik Semen PT. Semen Indonesia (persero) TBK di Kabupaten Rembang Provinsi Jawa Tengah. Namun Ganjar Pranowo kembali mengeluarkan izin baru untuk Semen Indonesia di Rembang, Jawa Tengah.

Surat Putusan Gubernur Jawa Tengah yang baru dapat dikatakan menyalahi aturan UndangUndang yang berlaku di Indonesia. Sehingga terjadi pembangkangan hukum oleh Gubernur Jawa Tengah karena tidak menjalankan putusan Mahkamah Agung yang dengan jelas ditegaskan dalam Tata urutan undang-undang bahwa Mahkamah Agung merupakan lembaga peradilan tertinggi diantara peradilan yang lainnya (Atmaja, 2010). Seperti yang tercantum dalam UU No 12 Tahun 2011 Tentang Pembentukan Peraturan Perundang-Undangan pasal 9 ayat 2 bahwa suatu peraturan perundang-undangan di bawah UndangUndang diduga bertentangan dengan UndangUndang, pengujiannya dilakukan oleh Mahkamah Agung. Sedangkan dalam kasus ini Surat Gubernur Jawa Tengah yang merupakan putusan yang berada di bawah putusan Mahkamah Agung. 


\section{Jurnal Cakrawala Hukum, Volume 10 No. 1 Juni 2019}

ISSN PRINT 2356-4962 ISSN ONLINE 2598-6538

\section{Simpulan}

Pembangunan pabrik semen oleh PT Semen Indonesia di kawasan batu karsa dan kawasan cekungan air Pegunungan Kendeng menuai penolakan dari warga sekitar. Selain memberikan dampak negatif bagi masyarakat sekitar juga memberikan dampak negatif bagi lingkungan. Upaya penambangan di kawasan karst Watuputih dinilai sejumlah kalangan merupakan sebuah bentuk pelanggaran. Kasus ini ada beberapa peraturan yang dilanggar sehingga izin lingkungan tersebut tidak sah secara hukum karena bertentangan dengan banyak peraturan perundang-undangan yang ada sehingga izin tersebut mengandung cacat hukum, kekeliruan, penyalahgunaan, serta ketidakbenaran dan/ atau pemalsuan data, dokumen, dan/ atau informasi, namun sampai saat ini oprasional pabrik PT Semen Indonesia telah berjalan dengan dasar legaliltas Izin Lingkungan baru tersebut.

Pembangkangan hukum oleh Gubernur Jawa Tengah karena tidak menjalankan putusan Mahkamah Agung yang dengan jelas ditegaskan dalam Tata Urutan Undang-Undang bahwa Mahkamah Agung merupakan lembaga peradilan tertinggi diantara peradilan yang lainnya. Seperti yang tercantum dalam UU No 12 Tahun 2011 tentang pembentukan peraturan perundang-undangan pasal 9 ayat 2 bahwa suatu peraturan perundang-undangan di bawah Undang-Undang diduga bertentangan dengan Undang-Undang, pengujiannya dilakukan oleh Mahkamah Agung. Sedangkan dalam kasus ini Surat Gubernur Jawa Tengah yang merupakan putusan yang berada di bawah putusan Mahkamah Agung.

\section{Daftar pustaka}

Abe, Alexander. 1994. Perancangan Daerah Administratif. Yogjakarta. Pustaka Yogjakarta Mandiri.

Atmaja, Ardita Yuliana. 2010. Implementasi Peraturan Daerah No 14 Tahun 1998 tentang Retribusi Izin Gangguan di Kota Surakarta. Surakarta. Program
Pasca Sarjana Ilmu Hukum Universitas Sebelas Maret.

Febrian. 2004. Hirarki Aturan Hukum di Indonesia. Disertasi. Universitas Airlangga.

Hadjon, Philipus M. 1994. Pengantar Hukum Perizinan. Bandung. Alumni.

Kaloh, J. 2009. Kepemimpinan Kepala Daerah: Pola Kegiatan, Kekuasaan dan perilaku Kepala Daerah dalam Pelaksanaan Otonomi Daerah. Jakarta. Sinar Grafika.

Keputusan Presiden Republik Indonesia Nomor 26 Tahun 2011 tentang Penetapan Cekungan Air Tanah.

Marzuki, Peter Mahmud. 2017. Penelitian Hukum. Jakarta. Kencana Predana Media.

Mertokusumo, Sudikno. 2005. Mengenal Hukum Suatu Pengantar Yogyakarta. Liberty.

Nasution, Bahder Johan. 2008. Metode Penelitian Ilmu Hukum. Bandung. Mandar Maju.

Peraturan Daerah Nomor 9 Tahun 2002 tentang Retribusi Izin Mendirikan Bangunan.

Peraturan Menteri Dalam Negeri Nomor 24 Tahun 2006 tentang Pedoman Penyelenggaraan Pelayanan Terpadu Satu Pintu.

Putusan Mahkamah Agung No 99 PK/TUN/2016 tentang Pembatalkan Izin Atas Surat Izin yang Dikeluarkan oleh Gubernur Jawa Tengah.

Sibuea, Hotma. 2010. Asas Negara Hukum, Peraturan Kebijakan, dan Asas-Asas Umum Pemerintahan yang Baik. Jakarta. Erlangga.

Soekanto, Soerjono dan Sri Mamudji. 2011. Penelitian Hukum Normatif Suatu Tinjauan Singkat. Jakarta. Raja Grafindo Persada.

Sunarno, Siswanto. 2009. Hukum Pemerintahan Daerah. Jakarta. Sinar Grafika.

Supriatna, Tyahya. 1996. Sistem Administrasi Pemerintahan di Daerah. Jakarta. Bumi Aksara.

Surat Keputusan Gubernur Jawa Tengah Gubernur No 660.1/30 Tahun 2016 tentang Izin Lingkungan Kegiatan Penambangan Dan Pembangunan Pabrik Semen PT Semen Indonesia di Kabupaten Rembang.

Surat Keputusan Gubernur Jawa Tengah Nomor 660.1/ 4 Tahun 2017 Tanggal 16 Januari 2017 tentang 
Keabsahan Surat Keputusan Gubernur Jawa Tengah Pasca Putusan Mahkamah Agung...

Zainuddin Amriti Albar

Izin Lingkungan Kegiatan Penambangan dan Pembangunan Pabrik Semen PT Semen Indonesia di Kabupaten Rembang.

Sutedi, Adrian. 2013. Hukum Perizinan Dalam Sektor Pelayanan Publik. Jakarta. Sinar Grafika.

Undang-Undang No. 32 tahun 2009 tentang Perlindungan dan Pengelolaan Lingkungan Hidup.
Undang-Undang Republik Indonesia Nomor 12 Tahun 2011 tentang Tata Urutan Perundang-Undangan.

Undang-Undang Republik Indonesia Nomor 32 Tahun 2004 tentang Pemerintahan Daerah.

Undang-Undang Republik Indonesia Nomor 7 Tahun 2004 tentang Sumberdaya Air. 
